\title{
GEOLOGICAL RECONNAISSANCE OF THE PRECAMBRIAN ROCKS OF SOUTH-EAST GREENLAND
}

\section{Bridgwater and K. Gormsen}

The Precambrian of SE Greenland can be divided into three main structural units; a northern block affected by the eastern continuation of the Nagssugtoqidian orogeny; a southern block affected by the Ketilidian orogeny; and a central block of gneisses unaffected by these younger events. The boundaries of the younger orogenies can be seen in the field by their effect on basic dyke swarms intruded into the older basement. With the exception of younger intrusive complexes, the rocks so far mapped within the two younger orogenic complexes in this part of Greenland are all derived from an older basement.

This report deals mainly with the rocks of the central gneiss block and the transitional zone between it and the rocks involved in the Nagssugtoqidian orogeny. Additional information on the petrology of the Nagssugtoqidian rocks was given by Bridgwater and Gormsen (1968). The present mapping stopped at the northern boundary of the effects of the Ketilidian orogeny. The central gneiss block extends approximately from Gyldenl $\phi$ ves Fjord $\left(64^{\circ} 15^{\prime}\right)$ to Tingmiarmiut Fjord $\left(62^{\circ} 35^{\prime}\right)$. The dominant rock type found in the central block is an inhomogeneous agmatitic gneiss with fragments of dark, generally hornblende-rich, material set in a leucocratic granodioritic ground mass. The agmatites themselves are not markedly foliated; occasionally local trains of inclusions with a distinctive character can be used to measure regional structural trends. The agmatites are believed to represent fragments of older layered gneisses which have been broken up and partially mobilised during one or more periods of intense regional metamorphism and anatexis. In several areas the agmatites show a more marked.structure which has been impressed on them after their original formation. This impressed foliation is particularly noticable in SE-NW trending belts up to $50 \mathrm{~km}$ wide where the gneisses have a constant foliation. 
The fragments in the agmatites contain several distinctive rock types, for example gabbro anorthosite inclusions (found in the Tingmiarmiut Fjord and Ikerssuaq areas) and enstatite-fosterite-tremolite blocks. Subconcordant partly broken-up layers of amphibole-orthopyroxene rock with subsiduary olivine and garnet occur in the gneisses between Bernstorffs Isfjord and Tingmiarmiut Fjord.

Supracrustal horizons are sporadically distributed; they are more marked in areas approaching the Inland Ice and have a regional approximately coast-parallel NNE-SSW trend locally disrupted by the SE-NW belts of younger deformation. There is a higher proportion of volcanic material in the supracrustal rocks in the south of the area.

The supracrustal rocks are always preserved as conformable layers in the agmatitic gneisses, the sequences vary from several kilometres to a few metres in thickness. Individual sequences can be traced for 50 or more kilometres along their strike; they finally become attenuated and broken up so that they are no longer mappable as separate units in the agmatites. The main belts of supracrustal rocks are regarded as original sedimentary and volcanic material laid down on an older basement now represented by the major part of the agmatitic gneisses. The only age determination so far carried out on supracrustal rocks from the central gneiss block (a biotite gneiss from close to Tingmiarmiut weather station) gives a K/Ar age of $2190 \mathrm{~m} \cdot \mathrm{y}$. (O. Larsen, this report). This date is unlikely to reflect the age of the main metamorphism of the supracrustal sequence since the area has been heavily invaded by a large number of late tectonic pre-Ketilidian granites. Furthermore the sample comes from an area in which the preKetilidian dykes are beginning to show the effects of a younger metamorphism and it is throught likely that the 2190 date may reflect a partial updating comparable to K/Ar ages obtained on gneisses from the Frederikshåb area of West Greenland. The supracrustal rocks can be seen to have passed through so complex a history that they are believed to represent material laid down earlier than $2600 \mathrm{~m} . \mathrm{y}$.

The original unconformities between supracrustal rocks and the still older basement have been destroyed by one or more periods of deformation and anatexis so that the present boundary between agmatite and cover (commonly a migmatite front) now lies within the original supracrustal rocks. No sediments corresponding to the geosynclinal phase of the 
Ketilidian and Nagssugtoqidian orogenies have been found between Angmagssalik and Tingmiarmiut.

The metasediments described in this report from within the younger fold belts are regarded as belonging to the same main period of deposition as those in the central block although no exact correlations are possible. Presumed Ketilidian semipelitic migmatites have been seen from the air farther south at the head of Danells Fjord and are thought to be the direct continuation of the metasedimentary sequences of the Nanortalik area.

All major occurrences of supracrustal rock are accompanied by ultrabasic intrusions concentrated in the transitional zones between cover and basement. These were apparently emplaced early in the metamorphic history of the cover rocks. Where little recrystallised they contain enstatite and fosterite as the main rock-forming minerals.

The central block contains scattered relics of gneisses showing granulite facies mineralogy. This is demonstrably later than an early amphibolite facies metamorphism which affected both the agmatites and the supracrustal rocks but was affected by regional retrograde metamorphism before the onset of Ketilidian/Nagssugtoqidian orogenies. Granulite facies rocks are particularly common in the ESE-WNW-trending structural belt which runs along the length of Skjoldungen island. Anatexis accompanied by basic and intermediate activity took place under the high grade metamorphic conditions with the production of intrusive charnockitic granites.

The regional retrogression of the granulite facies rocks was accompanied by the formation of several late tectonic diorites and granites. The diorites are commonly discordant sheets, in some cases with net-veined margins; the granites are more diffuse subconcordant bodies with migmatitic contacts. One discordant sheet of corundum-bearing diorite with copious pale mica and epidote has been noted in the Umîvik area.

Basic dyke swarms. The gneisses are cut by several swarms of basic dykes, some of which are affected by the younger orogenies to the north and south. In the southern part of the area the pre-Ketilidian dykes were emplaced under relatively stable conditions. Two main types of dyke are recognised: a single presistent $140^{\circ}$ hypersthene dolerite resembling the early Kangamiut dykes of West Greenland (Berthelsen and Bridgwater, 1960 ), and a younger swarm of ENE to $E-W$ dolerites which are common between Bernstorffs Isfjord and Tingmiarmiut. These dykes show the 
effects of a progressively increasing static metamorphism south and west of Tingmiarmiut fjord so that when seen at the margins of the Inland Ice towards the head of Tingmiarmiut Fjord they resemble the pre-Ketilidian metadolerites described from Tôrnârssuk in the NW Ivigtut area (Bondesen and Henriksen, 1965)。

In the Tingmiarmiut area the early basic dykes are cut by at least three groups of post-metamorphic intrusions. The oldest is a series of flat-lying sills ranging from dolerite to hornblende diorites (appinites). These are accompanied by small carbonatitic masses containing fosteritic olivine, albite, diopside, scapolite and carbonate. 'They are regarded as the northernmost occurrences of the late Ketilidian calc-alkaline suite. They are cut by two sets of (presumed) Gardar dolerites. The earliest, a swarm of NNW to N-S dolerites is found throughout the area south of Bernstorffs Isfjord; the youngest is only found south of $62^{\circ} 40^{\prime \prime}$ and consists of broad (25-100 m) olivine dolerites trending ca. $80^{\circ}$ which resemble the more basic Gardar dykes of SW Greenland. This swarm reaches its maximum density at about $62^{\circ}$. Numerous fragments of sandstone dykes are found in local corrie glacier screes on Tingmiarmit island and it is thought that the original Gardar land surface may have lain just above the present erosion level.

Between Umivik and Kungmiut to the north of Angmagssalik there are very extensive swarms of basic dykes which have been affected by the Nagssugtoqidian orogeny. The most persistent original trend in approximately WNW, parallel with the margin of the younger fold belt. It is thought that the original distribution of the dykes and perhaps some of their petrological peculiarities (see Bridgwater and Gormsen, 1968) may have been controlled by processes which later controlled the main trend of the following orogeny. In Umivik, at the southern limit of the Nagssugtoqidian, the dykes are moderately rectilinear and doleritic in composition. Farther north, where the overall effect of the Nagssugtoqidian orogeny has been much stronger, basement enclaves are preserved little affected by the younger movements. The dykes preserved in these enclaves show original irregular intrusion forms and many apophyses. Many were apparently water-rich at the time of their original crystallisation and there are many bodies which contain an abnormally high proportion of olivine and pyroxene. 


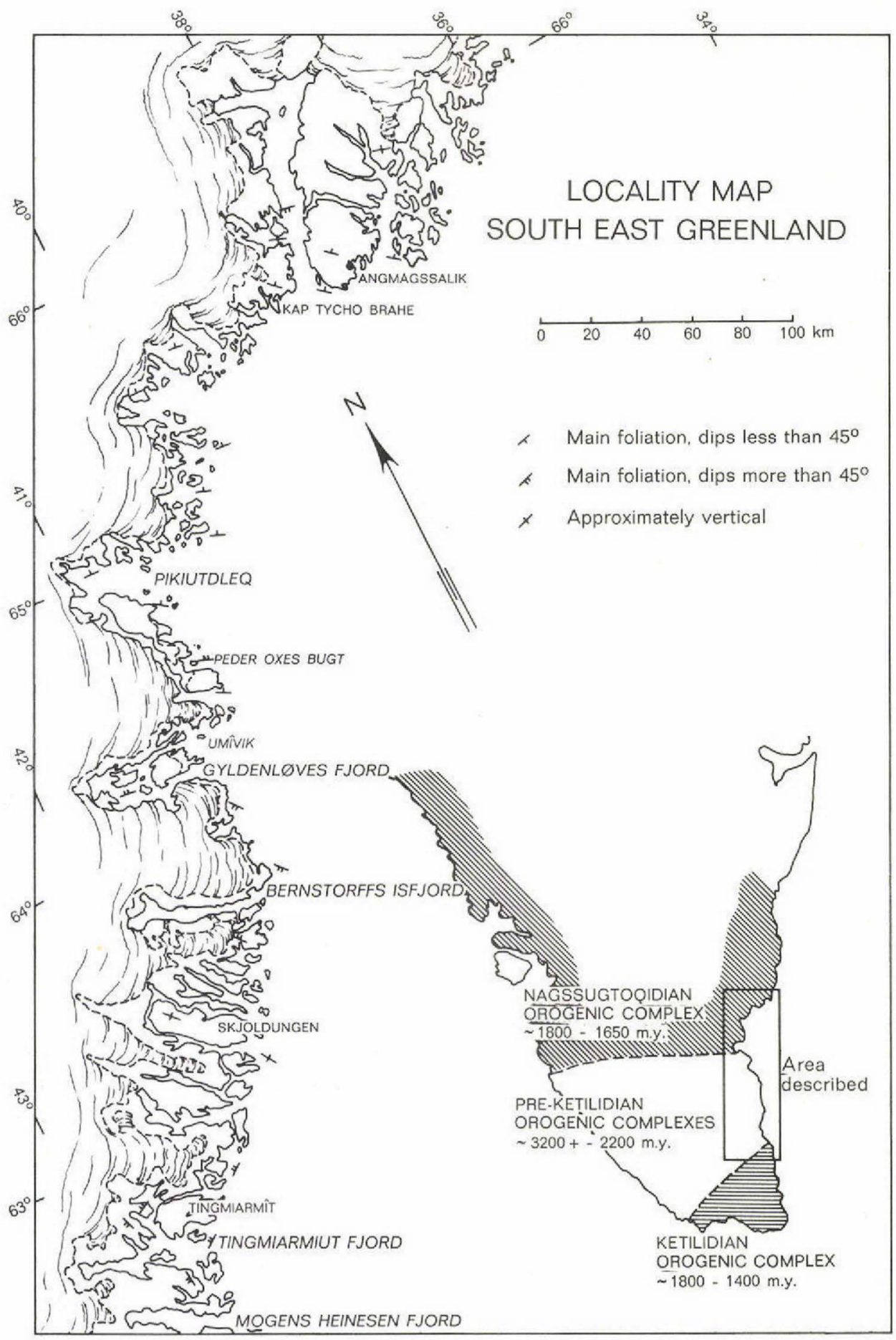


While the dykes can be used in the classic manner at the margin of the fold belt to divide areas which remained stable from areas reworked by the younger earth movements, the features shown by the dykes which were later to be nearex the centre of the younger fold belt suggest that they were intruded in unstable conditions. It seems possible that much of the area now occupied by the Nagssugtoqidian fold belt may have been unstable before the main orogenic event dated between 1700 and $1800 \mathrm{~m}$. y. Effects of the Nagssugtoqidian orogeny. The most noticable effect of the Nagssugtoqidian deformation on the earlier gneisses is the production of a series of E-W to ESE-WNW-trending belts of highly schistose rocks with shallow dips towards the north and strong linear features plunging NW. The character of the deformation shows a progressive change from the margin of the orogeny northwards. The most southerly of the belts of strong deformation occurs in Peder Oxes Bugt where the basement gneisses and the metadolerite dykes are involved in a belt of intense flattening approximately $2 \mathrm{~km}$ wide. The margins of the belt are knife sharp; within the belt flattening is intense and earlier structures are almost completely destroyed. Small eyes of undeformed rock 20-30 $\mathrm{m}$ across occur within the belt. The gneisses and metadykes adjacent to the belt are almost undeformed although locally an imbricate structure develops with blocks of undeformed rock partly rotated in an anastomising set of deformed zones. Northwards there is an increasing number of deformed rocks and the belts become broader with less well defined margins. In the first $50 \mathrm{~km}$ from the margin no major folds are recognised associated with these structures although earlier discordant bodies such as the metadykes may show isoclinal kink structures. On the north side of Ikerssuaq and on Kap Tycho Brahe nappe structures are seen refolding north-south folds which themselves refold earlier structures in the metasediments. Towards the presumed central zone of the Nagssugtoqidian fold belt the metamorphic grade increases and it becomes increasingly difficult to distinguish pre-existing features from Nagssugtoqidian structural and metamorphic events. The distribution pattern of supracrustal rocks changes so that instead of the moderately straight belts seen farther south they are preserved as irregular infolded areas between deformed domes of older basement. Some granulite facies metamorphism occurred in the Angmagssalik area associated with the emplacement of a syntectonic basic charnockite suite. The granulites are commonly 
downgraded by the effects of the youngest movements on the WNW-trending structures.

The youngest Precambrian events in the area were the generation of high-level faulting and shearing sometimes accompanied by mylonitisation. This commonly occurred parallel to the regional WNW structures.

Approximately coast-parallel Tertiary dolerite dykes are found between Angmagssalik and Umivik. Small carbonatites of presumed Tertiary age are found in two localities: in a N-S fault zone on the south side of Peder Oxes Bugt, and cutting the metasediments $20 \mathrm{~km}$ to the west of Kap Tycho Brahe. Single zeolite-bearing $\mathrm{E}-\mathrm{W}$ dykes on Tingmiarmit island are the only other possible Tertiary activity noted from the area.

Future investigations. The reconnaissance mapping carried out in the last two summers can only be regarded as a start to work in the area. Enough information has been obtained to give the broad outline of Precambrian events in SE Greenland and these can now be compared with Precambrian events in other parts of the North Atlantic shield.

The areas between Mogens Heinesen fjord and Lindenows fjord to the south and between Angmagssalik and Scoresby Sund to the north still require reconnaissance and this must be the prime objective of further work. The last two summers field work have been carried out using a $20 \mathrm{ft}$ open motor boat. This proved adequate in the area between Angmagssalik and Umîik and although the lack of protection was tiring the manoeuvrability and low cost (approximately $12000 \mathrm{kr}$. for 2 years) means that the method had much to recommend it. South of Umivik too much reliance has to be placed on good ice conditions and stable weather for the writers to wish to undertake this part of the journey again unless accompanied by a larger base ship. Between Tingmiarmiut and Prins Christians Sund the use of a small boat seems out of the question unless the sea ice is particularly thick and acts as a protection. However there seems no reason, given an experienced captain, why a 30-40 ft cutter could not be used in the area especially since the boat will be in easy range of helicopters based at Narssarssuaq or at the Loran Station at Qutdleq. In reasonable conditions it is possible to sail from Tingmiarmiut to Nanortalik in four days. North of Angmagssalik the $20 \mathrm{ft}$ motor boat could possibly be used as far north as $66^{\circ} 25^{\prime}$ and could be transported at reasonable cost by hiring the KGH sealers based on Angmagssalik so that the larger fjords as far north as Kangerdlugssuaq could 
be mapped. The main coast is however too open and devoid of anchor places to rely on mapping this coast using small boats and it would seem better to use the same methods as those now in practise in Scoresby Sund.

\section{References}

Bondesen, E. and Henriksen, N. (1965) On some pre-Cambrian metadolerites from the central Ivigtut region SW Greenland. Bull. Grфnlands geol. Unders., No. 52 (also Meddr Grфnland, Bd. 179, Nr. 2 ). Berthelsen, A. and Bridgwater, D. (1960) On the field occurrence and petrography of some basic dykes of supposed pre-Cambrian age from the southern Sukkertoppen district western Greenland. Bull. Grønlands geol. Unders., No. 24 (also Meddr Grфnland, Bd. 123, $\mathrm{Nr} .3$ ).

Bridgwater, D. and Gormsen, K. (1968) Precambrian rocks of the Angmagssalik area, East Greenland. Rapp。Grфnlands geol. Unders., Nr. 15, 61-71.

FIELD MAPPING IN THE INNER PART OF THE

SCORESBY SUND AREA, EAST GREENLAND

\section{Niels Henriksen}

A five year systematic field mapping programme in the Scoresby Sund area of East Greenland between $70^{\circ} \mathrm{N}$ and $72^{\circ} \mathrm{N}$ was begun in the summer of 1968. The expedition was based on the 1200 tons polar vessel "Martin Karlsen" which carried 2 Bell helicopters (chartered from Heliswiss, Berne) and supported a few small boats. 31 expedition members and a boat crew of 20 persons participated in the expedition which lasted approx. 2 months. The expedition members included 12 two-man geological parties of which 7 mapped in the crystalline complex in inner Nordvestfjord 